Authors' Contribution:

A Study Design

B Data Collection

C Statistical Analysis

D Data Interpretation

E Manuscript Preparation

F Literature Search

G Funds Collection

\title{
Endurance skills of young team game players
}

\author{
Paweł Chmura ${ }^{1 \mathrm{ADE}}$, Kamil Świerzko ${ }^{1 \mathrm{BDE}}$, Justyna Andrzejewska2 ${ }^{\mathrm{BD}}$, Marek \\ Popowczak $^{1 \text { ABD }}$, Andrzej Dudkowski ${ }^{18 D}$, Marek Konefał ${ }^{2}$ BC, Andrzej Rokita ${ }^{1}$ AG \\ ${ }^{1}$ Chair of Team Sports Games, University School of Physical Education in Wroclaw \\ ${ }^{2}$ Chair of Athletes' Motor Skills, University School of Physical Education in Wroclaw
}

\section{abstract}

Background The aim of the present study was to assess physiological-biochemical reactions to incremental exercise loads and the levels and development of endurance skills in young male and female team game players.

Material/Methods

The study sample comprised 370 soccer, handball, basketball and volleyball players (186 girls and 184 boys) from the Lower Silesian Regional Teams in Poland, aged 14.20 \pm 1.37 years (boys) and $13.90 \pm 1.15$ years (girls). The exercise test consisted ofthe shuttle run Beep Test for estimation of aerobic fitness. The assessment of endurance skills was based on the length of the covered distance in the Beep Test as well as on measurements of the heart rate (physiological) and blood lactate concentration (metabolic).

Results Among the four studied groups of players a statistically significant improvement in endurance skills was noted in male volleyball players ( $p \leq 0.05)$.

Conclusions Significantly higher levels of endurance skills in young male handball, basketball and volleyball players and in female volleyball players who remained on the regional teams for two consecutive years may be an indication of the players' proper selection and training. Significant changes in blood lactate concentration in young players, revealed in both cross-sectional and continuous studies, were only noted in male volleyball players. Significant decreases in the heart rate in the cross-sectional study was found only in male handball and basketball players and in female basketball players, whereas in the continuous study only in male handball players. An assessment of young players' physiological-biochemical reactions on the basis of exercise test results can effectively enhance the optimization of training loads.

Key words endurance, team games, selection, Beep Test, lactate, heart rate

\section{article details}

Article statistics

Full-text PDF:

Copyright

Indexation:

Funding:

Conflict of interest: Corresponding author:

Open Access License:
Word count: 4,368; Tables: 3; Figures: 0; References: 35

Received: May 2015; Accepted: July 2015; Published: September 2015

http://www.balticsportscience.com

() Gdansk University of Physical Education and Sport, Poland

AGRO, Celdes, CNKI Scholar (China National Knowledge Infrastructure), CNPIEC, De Gruyter - IBR (International Bibliography of Reviews of Scholarly Literature in the Humanities and Social Sciences), De Gruyter - IBZ (International Bibliography of Periodical Literature in the Humanities and Social Sciences), DOA], EBSCO - Central \& Eastern European Academic Source, EBSCO - SPORTDiscus, EBSCO Discovery Service, Google Scholar, Index Copernicus, J-Gate, Naviga (Softweco, Primo Central (ExLibris), ProQuest - Family Health, ProQuest - Health \& Medical Complete, ProQuest - Illustrata: Health Sciences, ProQuest - Nursing \& Allied Health Source, Summon (Serials Solutions/ProQuest, TDOne (TDNet), Ulrich's Periodicals Directory/ulrichsweb, WorldCat (OCLC)

The study is part of the research project no. RSA2 019 52: “Estimation of young people's predispositions to train sport team games" carried out in the years 2013-14.

Authors have declared that no competing interest exists.

Paweł Chmura, University School of Physical Education, Al. I.J. Paderewskiego 35, 51-612 Wrocław, Poland; office telephone number: 0048713473564; e-mail: pawel.chmura@awf.wroc.pl

This is an open access article distributed under the terms of the Creative Commons Attribution-Non-commercial 4.0 International (http://creativecommons.org/licenses/by-nc/4.0/), which permits use, distribution, and reproduction in any medium, provided the original work is properly cited, the use is non-commercial and is otherwise in compliance with the license. 


\section{INTRODUCTION}

One of the major issues in modern sport has been lack of talent identification. There is a pressing need to lay down strict selection criteria that will enable children with sport predispositions to attain top results in particular sport disciplines [1]. It seems to be fully justified that sports talents should be sought also on the basis of results of general fitness tests [2].

Identification of motor abilities in young people during the period of their most intensive biological development is crucial. This period is decisive for the prospective sports careers of young people, whether amateur or professional. The process of selection for particular sports is a complex one. It involves undertaking a number of actions aimed at elimination of those individuals who guarantee no prospective success in particular sports. In their decision-making sport coaches consider candidates' somatic build, fitness, personality traits, technical and tactical skills and - regarded as the most important - motor skills [3-5]. This has been confirmed by Reilly et al. [2] and Malina et al. [6].

The training of talented young members of Polish Regional Teams in various team games places a particular emphasis on the control of physical loads, as successful sport performance is determined by multiple factors [7]. From the practical point of view regular control of athletes allows coaches to find answers to a number of key questions: Do trainees attain better results in successive tests? Is the training process correct? Is there an improvement in trainees' sport-specific motor skills? Have there been any overloads or underloads of trainees' bodies?

Studies in morphology, physiology, neurophysiology, psychophysiology, and exercise biochemistry clearly indicate considerable differences between individuals in terms of muscle cells, motor units, stimulation rates, metabolic processes, and enzymatic activity [8]. Thus, individualization of training loads is necessary for the development of motor skills. It can only be achieved if objective data about anathlete's body is available. To obtain such data different exercise tests should be used on a regular basis. It has been proven that appropriate training methodology, forms, and means used during periods in which a given motor skill develops faster (so-called sensitive periods) are much more effective [1]. The effect of stimulation is greater, if exercise loads correspond with young athletes' biological abilities. On the other hand, coaches' ignorance of the sensitive periods in the training process leads to slower development of a given motor skill [9]. Researchers also point to the need of regular monitoring of training loads in team games, which guarantees the optimal development of players' motor skills [7, 10].

In sports team games the variability, acyclical character, performance intensity and dynamics depend on players' positions on the pitch, game tactics and - first of all - on players' levels of motor skills [11]. Moreover, each team sport is based on individual actions of players who must master numerous motor habits, i.e. intended and thoroughly planned reactions to the opponent's actions [12]. Soccer, handball and basketball share many similarities in relation to the structure of human movement, and are classified as directly competitive sports. Players during matches perform a great number of complex activities with and without the ball, such as jogging, low-, medium- and 
high-intensity running, changing paces, sprinting and jumping. All these activities, which have been acquired earlier, should be controlled and refined. Many sport coaches also stress the role of players' volitional traits, and consider players' mental predispositions as decisive in modern sport [13, 14].

Endurance in team sports is manifested by the readiness to perform repeated short-lasting efforts by soccer, handball, and basketball players, and explosive exercises by volleyball players. Physiologically, two types of endurance can be distinguished: aerobic and anaerobic [15, 16]. A high level of aerobic endurance enables players to develop and maintain high-intensity activities in match-play. It is also conducive to faster recovery during and after the game and constitutes abasis for good and stable sport fitness [17]. Anaerobic endurance is manifested by the ability to build up the oxygen debt and high tolerance to homeostasis imbalance. It allows players to develop maximal power in the shortest possible time over short distances at a high rate. The knowing and understanding of processes taking place in the human body enable coaches to prepare athletes much better before particular competitions and the entire competitive season. It was also noted that puberty is the most favorable period for developing endurance [18].

Gronek et al. [19, 20] stressed the need for genetic research in team sports, which can greatly facilitate the individualization of the training process. It should be emphasized that athletes' endurance, speed, and strength skills are genetically determined. Also the maximal oxygen uptake $\left(\mathrm{VO}_{2} \mathrm{max}\right)$, as a basic index of physical fitness, is associated with the athlete's genetic profile. Studies show that athletes with a higher $\mathrm{VO}_{2}$ max demonstrate higher performance [21]. Nikolaidis [22] observes that intensity in sports training, especially in team games, can also be assessed by the heart rate measured by exercise tests. In match-play the exercise intensity amounts to $80-90 \% \mathrm{HRmax}$ [23], and blood lactate concentration ranges between 2 and $10 \mathrm{mmol} / \mathrm{l}$ [24]. Le Meur et al. [25] recommend the monitoring of lactate concentration during training for estimation of possible underloads and overloads. It is, in fact, the most often applied biochemical index in sport practice.

Considering the dynamic development of motor skills in young athletes, aregular use of exercise tests is recommended. The aim of the present study was to assess physiological-biochemical reactions to incremental exercise loads and the dynamics of development of endurance skills in young male and female team game players.

\section{MATERIAL AND METHODS}

The study sample consisted of 370 young soccer, handball, basketball, and volleyball players (186 girls and 184 boys) from the Lower Silesia Regional Teams. Fifty-five of the selected participants took part in the exercise tests in 2013 and repeated them in 2014. The boys' mean body height was 175.20 $\pm 14.76 \mathrm{~cm}$, and girls' body height was $167.60 \pm 8.83 \mathrm{~cm}$. The boys' body mass was $62.70 \pm 15.51 \mathrm{~kg}$ and girls' body mass was $57.80 \pm 10.11 \mathrm{~kg}$. The boys' mean age was $14.20 \pm 1.37$ years, and the girls' $13.90 \pm 1.15$ years.

The multistage shuttle run test (Beep Test) was used in the study to measure aerobic fitness of sport training groups of children and youth [26, 27]. The 
assessment of endurance skills was carried out on the basis of the covered distance in the Beep Test. The exercise test took place in a gym, between 9.00 and 12.00, always in the same conditions. The shuttle run was performed over a $20 \mathrm{~m}$ distance, with increases in speed every minute signaled by recorded beeps. A run was completed when a participant was not able to continue running at a given speed. A standard Beep Test CD with recorded beeps was used to signal the incremental exercise intensities.

The monitoring of participants' endurance skills was on two levels: physiological - by recording the heart rate (HR), and metabolic - by measuring blood lactate concentration (LA). The heart rate was measured with the Polar Team 2 System. The HRmax attained by the end of the Beep Test was used for analysis. The blood lactate level was measured with a Lactate Scout apparatus (SensLab) with the measuring range of 0.5-25 mmol/l, using the enzymatic-amperometric method of measurement of capillary blood lactate [28, 29]. The measurements were carried out immediately after completion of the exercise test.

The analysis of the results was twofold. Firstly, cross-sectional studies of the players from Lower Silesia Regional Teams were carried out in 2013 and 2014. The levels of endurance skills in soccer, handball, basketball and volleyball were compared among the participants who were selected for the teams in 2013, who remained on the teams in 2014, who were not selected in 2014, and who were selected for the first time in 2014. Secondly, repeated tests were performed by participants who remained on the regional teams for two consecutive years, i.e. 2013 and 2014 .

The study was part of research project no. RSA2 01952 "Estimation of young people's predispositions to train sport team games" carried out in the years 2013-14, which has the approval of the Bioethics Committee.

The statistical analysis was carried out with the use of Statistica ver. 10.0 software package. Arithmetic means and standard deviations were calculated. To compare the mean values of examined variables, an ANOVA was performed. The differences between pairs of means were checked with Fisher's least significant difference (LSD) test. The levels of statistical significance were set at $\mathrm{p} \leq 0.05, \mathrm{p} \leq 0.01$ and $\mathrm{p} \leq 0.001$.

The tools and equipment for the study came from the certified Ball Games Lab (PN -EN ISO 9001:2009) of the Chair of Sports Team Games of the University School of Physical Education in Wroclaw.

\section{RESULTS}

\section{CROSS-SECTIONAL STUDY}

\section{Endurance skills}

Among the players from the Lower Silesian Regional Teams in 2013, the handball players who remained on the team in 2014 covered a significantly longer distance in the exercise test ( $p \leq 0.05$ ) than the players who were not selected for the 2014 season (Tab. 1). 
In 2014 a higher level of endurance skills was noted in players who repeated the exercise tests in 2014 than in players who did not remain on their teams for the next year: male basketball players ( $p \leq 0.05)$, male volleyball players $(p \leq 0.05)$, and female volleyball players $(p \leq 0.01)$.

Table 1. The covered distance [m] in cross-sectional and continuous studies of players who did not repeat $(N-R)$ and who repeated $(R)$ the shuttle run exercise test

\begin{tabular}{|c|c|c|c|c|c|c|c|c|c|}
\hline \multirow{3}{*}{ Sex } & \multirow{3}{*}{ Year } & \multicolumn{2}{|c|}{ Soccer } & \multicolumn{2}{|c|}{ Handball } & \multicolumn{2}{|c|}{ Basketball } & \multicolumn{2}{|c|}{ Volleyball } \\
\hline & & N-R & $\mathrm{R}$ & N-R & $\mathrm{R}$ & N-R & $\mathrm{R}$ & N-R & $\mathrm{R}$ \\
\hline & & \multicolumn{8}{|c|}{$\mathrm{x} \pm \mathrm{SD}$} \\
\hline \multirow{2}{*}{ M } & 2013 & $\begin{array}{l}1678.46 \\
\pm 400.95\end{array}$ & $\begin{array}{l}1700.00 \\
\pm 603.99\end{array}$ & $\begin{array}{l}1791.82 * \\
\pm 435.55\end{array}$ & $\begin{array}{c}2084.44 * \\
\pm 292.54\end{array}$ & $\begin{array}{l}1832.50 \\
\pm 453.86\end{array}$ & $\begin{array}{l}1632.50 \\
\pm 290.41\end{array}$ & $\begin{array}{l}1584.76 \\
\pm 308.22\end{array}$ & $\begin{array}{c}1570.00 \# \\
\pm 457.95\end{array}$ \\
\hline & 2014 & $\begin{array}{l}1977.93 \\
\pm 356.26\end{array}$ & $\begin{array}{l}2193.33 \\
\pm 533.04\end{array}$ & $\begin{array}{l}1806.32 \\
\pm 348.91\end{array}$ & $\begin{array}{l}1931.11 \\
\pm 423.69\end{array}$ & $\begin{array}{l}1530.00 * \\
\pm 507.02\end{array}$ & $\begin{array}{c}1932.50 * \\
\pm 305.18\end{array}$ & $\begin{array}{c}1668.00 * \\
\pm 473.09\end{array}$ & $\begin{array}{c}1995.00^{*} \# \\
\pm 400.82\end{array}$ \\
\hline \multirow{2}{*}{ W } & 2013 & $\begin{array}{l}1317.14 \\
\pm 347.26\end{array}$ & $\begin{array}{l}1348.00 \\
\pm 243.97\end{array}$ & $\begin{array}{l}1173.33 \\
\pm 231.89\end{array}$ & $\begin{array}{l}1240.00 \\
\pm 213.54\end{array}$ & $\begin{array}{l}1284.44 \\
\pm 332.73\end{array}$ & $\begin{array}{l}1540.00 \\
\pm 300.89\end{array}$ & $\begin{array}{l}1069.09 \\
\pm 285.85\end{array}$ & $\begin{array}{l}1234.55 \\
\pm 261.09\end{array}$ \\
\hline & 2014 & $\begin{array}{l}1451.72 \\
\pm 320.43\end{array}$ & $\begin{array}{l}1572.00 \\
\pm 130.84\end{array}$ & $\begin{array}{l}1216.19 \\
\pm 338.09\end{array}$ & $\begin{array}{l}1295.00 \\
\pm 268.02\end{array}$ & $\begin{array}{l}1490.59 \\
\pm 301.34\end{array}$ & $\begin{array}{l}1697.14 \\
\pm 315.69\end{array}$ & $\begin{array}{c}1009.23^{* *} \\
\pm 260.28\end{array}$ & $\begin{array}{c}1330.91 * * \\
\pm 242.71\end{array}$ \\
\hline
\end{tabular}

Statistically significant difference in the cross-sectional study:

$*(p \leq 0.05) ; * *(p \leq 0.01) ; * * *(p \leq 0.001)$

Statistically significant difference in the continuous study:

$\#(p \leq 0.05)$; \#\# ( $\mathrm{p}$ 0.01); \#\#\# ( $\leq$ 0.001)

\section{Lactate blood concentration}

In 2013 the test results revealed that male volleyball players attained a statistically higher lactate level after the Beep Test $(\mathrm{p} \leq 0.05)$. In players who did not repeat the exercise tests the lactate concentration was $11.84 \pm 3.21$ $\mathrm{mmol} / \mathrm{l}$, while in the selected players it amounted to $15.08 \pm 4.35 \mathrm{mmol} / \mathrm{l}$ (Tab. 2). In 2014 no statistically significant differences were found.

Table 2. Blood lactate concentration [ $\mathrm{mmol} / \mathrm{l}]$ in cross-sectional and continuous studies of players who did not repeat $(N-R)$ and who repeated $(R)$ the shuttle run exercise test

\begin{tabular}{|c|c|c|c|c|c|c|c|c|c|}
\hline \multirow{2}{*}{ Sex } & \multirow{2}{*}{ Year } & \multicolumn{2}{|c|}{ Soccer } & \multicolumn{2}{|c|}{ Handball } & \multicolumn{2}{|c|}{ Basketball } & \multicolumn{2}{|c|}{ Volleyball } \\
\hline & & $N-R$ & $\mathrm{R}$ & $N-R$ & $\mathrm{R}$ & $N-R$ & $\mathrm{R}$ & $\mathrm{N}-\mathrm{R}$ & $\mathrm{R}$ \\
\hline & & \multicolumn{8}{|c|}{$x \pm S D$} \\
\hline \multirow{2}{*}{$M$} & 2013 & $\begin{array}{c}8.72 \\
\pm 2.68\end{array}$ & $\begin{array}{c}10.33 \pm \\
4.96\end{array}$ & $\begin{array}{l}12.13 \\
\pm 5.49\end{array}$ & $\begin{array}{l}12.77 \\
\pm 2.95\end{array}$ & $\begin{array}{l}10.07 \\
\pm 2.87\end{array}$ & $\begin{array}{c}9.99 \\
\pm 3.20\end{array}$ & $\begin{array}{l}11.84^{*} \\
\pm 3.21\end{array}$ & $\begin{array}{c}15.08 * \# \\
\pm 4.35\end{array}$ \\
\hline & 2014 & $\begin{array}{l}11.09 \\
\pm 3.96\end{array}$ & $\begin{array}{c}10.13 \pm \\
4.51\end{array}$ & $\begin{array}{l}14.24 \\
\pm 2.83\end{array}$ & $\begin{array}{l}12.76 \\
\pm 2.61\end{array}$ & $\begin{array}{l}11.56 \\
\pm 4.06\end{array}$ & $\begin{array}{l}11.44 \\
\pm 4.17\end{array}$ & $\begin{array}{l}12.55 \\
\pm 3.82\end{array}$ & $\begin{array}{c}11.76 \# \\
\pm 2.81\end{array}$ \\
\hline \multirow{2}{*}{ W } & 2013 & $\begin{array}{l}10.93 \\
\pm 3.28\end{array}$ & $\begin{array}{r}13.76 \\
\pm 4.45\end{array}$ & $\begin{array}{l}11.54 \\
\pm 4.04\end{array}$ & $\begin{array}{l}15.32 \\
\pm 5.86\end{array}$ & $\begin{array}{l}12.54 \\
\pm 4.24\end{array}$ & $\begin{array}{l}14.21 \\
\pm 2.84\end{array}$ & $\begin{array}{l}12.77 \\
\pm 4.52\end{array}$ & $\begin{array}{l}12.00 \\
\pm 2.94\end{array}$ \\
\hline & 2014 & $\begin{array}{l}10.60 \\
\pm 3.67\end{array}$ & $\begin{array}{c}12.20 \\
\pm 2.71\end{array}$ & $\begin{array}{l}10.92 \\
\pm 3.32\end{array}$ & $\begin{array}{l}12.52 \\
\pm 4.18\end{array}$ & $\begin{array}{l}12.58 \\
\pm 3.18\end{array}$ & $\begin{array}{r}14.19 \\
\pm 3.36\end{array}$ & $\begin{array}{l}11.99 \\
\pm 3.60\end{array}$ & $\begin{array}{l}12.92 \\
\pm 2.89\end{array}$ \\
\hline
\end{tabular}

Statistically significant difference in the cross-sectional study:

$*(p \leq 0.05) ; * *(p \leq 0.01) ; * * *(p \leq 0.001)$

Statistically significant difference in the continuous study:

\# $(p \leq 0.05)$; \#\# ( $\leq \leq 0.01)$; \#\# $(p \leq 0.001)$

\section{Heart rate}

No statistically significant differences in the heart rate between the examined groups of players were noted in 2013. In the tests carried out in 2014, a significantly lower heart rate was observed in the groups of male basketball 
players, female basketball players, and male handball players ( $\mathrm{p} \leq 0.05$ ) who remained on their teams in the following years than in the remaining players (Tab. 3). The biggest difference in heart rate, i.e. above $8 \mathrm{bpm}$, was noted in male handball players.

Table 3. Heart rate [bpm] in cross-sectional and continuous studies of players who did not repeat $(\mathrm{N}-\mathrm{R})$ and who repeated $(\mathrm{R})$ the shuttle run exercise test

\begin{tabular}{|c|c|c|c|c|c|c|c|c|c|}
\hline \multirow{2}{*}{ Sex } & \multirow{2}{*}{ Year } & \multicolumn{2}{|c|}{ Soccer } & \multicolumn{2}{|c|}{ Handball } & \multicolumn{2}{|c|}{ Basketball } & \multicolumn{2}{|c|}{ Volleyball } \\
\hline & & $N-R$ & $\mathrm{R}$ & $N-R$ & $\mathrm{R}$ & $N-R$ & $\mathrm{R}$ & $N-R$ & $\mathrm{R}$ \\
\hline & & \multicolumn{8}{|c|}{$x \pm S D$} \\
\hline \multirow{2}{*}{$M$} & 2013 & $\begin{array}{c}204.69 \\
\pm 9.45\end{array}$ & $\begin{array}{r}209.00 \\
\pm 5.57\end{array}$ & $\begin{array}{c}200.36 \\
\pm 7.88\end{array}$ & $\begin{array}{c}202.56 \# \# \\
\pm 6.91\end{array}$ & $\begin{array}{l}199.05 \\
\pm 6.89\end{array}$ & $\begin{array}{c}201.13 \\
\pm 6.27\end{array}$ & $\begin{array}{c}201.29 \\
\pm 7.05\end{array}$ & $\begin{array}{r}205.50 \\
\pm 8.04\end{array}$ \\
\hline & 2014 & $\begin{array}{c}204.10 \\
\pm 8.71\end{array}$ & $\begin{array}{c}207.67 \\
\pm 4.73\end{array}$ & $\begin{array}{c}199.68 * \\
\pm 9.67\end{array}$ & $\begin{array}{c}191.11 * \# \# \\
\pm 9.45\end{array}$ & $\begin{array}{c}202.94 * \\
\pm 8.00\end{array}$ & $\begin{array}{c}196.13 * \\
\pm 5.30\end{array}$ & $\begin{array}{l}189.00 \\
\pm 8.83\end{array}$ & $\begin{array}{r}207.25 \\
\pm 5.99\end{array}$ \\
\hline \multirow{2}{*}{ W } & 2013 & $\begin{array}{l}199.29 \\
\pm 13.47\end{array}$ & $\begin{array}{c}210.20 \\
\pm 6.65\end{array}$ & $\begin{array}{l}201.57 \\
\pm 11.53\end{array}$ & $\begin{array}{c}203.50 \\
\pm 9.15\end{array}$ & $\begin{array}{l}202.83 \\
\pm 12.37\end{array}$ & $\begin{array}{l}199.57 \\
\pm 5.38\end{array}$ & $\begin{array}{c}204.55 \\
\pm 8.28\end{array}$ & $\begin{array}{c}205.64 \\
\pm 7.50\end{array}$ \\
\hline & 2014 & $\begin{array}{c}203.97 \\
\pm 9.79\end{array}$ & $\begin{array}{c}211.60 \\
\pm 9.79\end{array}$ & $\begin{array}{c}202.19 \\
\pm 8.48\end{array}$ & $\begin{array}{c}202.00 \\
\pm 6.06\end{array}$ & $\begin{array}{c}205.65 * * \\
\pm 5.96\end{array}$ & $\begin{array}{c}195.57 * * \\
\pm 10.88\end{array}$ & $\begin{array}{c}205.62 \\
\pm 9.02\end{array}$ & $\begin{array}{r}204.45 \\
\pm 5.96\end{array}$ \\
\hline
\end{tabular}

Statistically significant difference in the cross-sectional study:

$*(p \leq 0.05) ; * *(p \leq 0.01) ; * * *(p \leq 0.001)$

Statistically significant difference inthe continuous study:

$\#(p \leq 0.05)$; \# $(p \leq 0.01)$; \#\# $(p \leq 0.001)$

\section{REPEATED MEASUREMENTS}

\section{Endurance skills}

Among the players of the examined four team games, a statistically significant improvement in endurance skills was noted in male volleyball players ( $\mathrm{p}$ $\leq 0.05$ ) (Tab. 1). In 2013 they covered a distance of 1,570 $\pm 457.95 \mathrm{~m}$, and in 2014 - $1995 \pm 400.82 \mathrm{~m}$. Only male handball players did not reveal an improvement in their endurance skills.

\section{Lactate blood concentration}

The lactate blood level was shown to have decreased in the group of male volleyball players ( $\mathrm{p} \leq 0.05$ ) (Tab. 2). It was $3.32 \mathrm{mmol} / \mathrm{l}$ lower after the exercise test. No significant changes were noted in the other groups of players.

\section{Heart rate}

The heart rate measurements in 2013 and 2014 showed a statistically significant decrease in HRmax ( $\mathrm{p} \leq 0.05$ ) only in the group of male handball players (Tab. 3). In 2013 it was $202.56 \pm 6.91 \mathrm{bpm}$, whereas in 2014 it amounted to $191.11 \pm 9.45 \mathrm{bpm}$.

\section{DISCUSSION}

The obtained study results indicate the usefulness of systematic exercise tests among sport team game players. The tests provide objective data necessary for selection of young athletes and for coaches' effective control of the training process. The measurements of endurance skills of team players in 2013 and 2014 with the Beep Test allowed the estimation of individual levels of players' endurance. Thanks to the possible application of the multistage shuttle-run test in mass studies, without expensive laboratory equipment, researchers can compare multiple results between individual players and teams. The applied test is a very simple and objective method of estimation of endurance as an important component of motor preparation [30], and is one of many tests verifying the accuracy of selection in sport [2, 31]. 
The analysis of results of cross-sectional studies showed that the process of selection for Regional Teams in 2013 was correct. Out of eight studied teams, slightly lower endurance predispositions were only found in the male basketball and volleyball players who were selected for the teams again in 2014, in comparison with those who were not. The boys and girls who were selected for all the teams in 2014 for the first time demonstrated lower levels of endurance skills than players who were on their teams for the second season. It can be assumed that players selected for the regional teams display lower levels of endurance predispositions, but while on the team, their coaches make further selection of those players with higher endurance skills than others.

The girls who remained on the regional teams for two years had a higher blood lactate concentration than the girls who were only selected for 2013. This can be explained by a higher activity of anaerobic glycolysis enzymes and higher tolerance of the body to incremental fatigue [17], which most likely results from better training experience. This tendency wasnot, however, observed in female volleyball players in 2013. Higher lactate levels after the Beep Test were also noted in male soccer and handball players, and significantly higher in male volleyball players ( $\mathrm{p} \leq 0.05$ ). In the other groups of players the lactate concentration remained at a similar level, or was lower in players who repeated the tests in 2014. This can probably be explained by the use of incorrect training stimuli for the development of endurance skills.

The cross-sectional studies demonstrated no significant changes in HRmax at the end of the incremental exercise test in the female teams. This means that the training process of these female players involved too few sport-specific training loads, especially of short duration and high intensity. Among the boys, a higher HRmax was noted in players who remained on the teams for two years than in the others, with the exception of male handball and basketball players in 2014.

A number of authors stress the volitional dimension of the performance of exercise tests, especially tests with incremental intensity [13, 32, 33]. Some players do perform the tests to the best of their ability, while others utilize their motor capabilities only partially. A coach should ensure that young athletes fully commit to the performance of exercise tests. Additionally, estimations of athletes' lactate concentration and the heart rate can help coaches eliminate those individuals who do not make full use of their exercise potential.

The continuous studies of players who performed the tests in 2013 and 2014 revealed a significant improvement in endurance skills in male volleyball players ( $p \leq 0.05$ ) and increases in all other groups with the exception of male handball players. The significant improvement in volleyball players may be indicative of the appropriate selection of endurance training means. It also appears that in a sport in which the players featured the lowest level of endurance skills, the secan be most easily improved through proper training. The fact that volleyball players covered a significantly longer distance with concurrently a significantly lower blood lactate concentration $(\mathrm{p} \leq 0.05)$ shows that endurance training was optimal for this particular group of players. It may come as a surprise since volleyball is characterized by short-lasting and explosive exercises rather than endurance exercises [34]. The lower levels of endurance skills in male handball players may be a result of their partial commitment to the test 
performance as indicated by their lower blood lactate and significantly lower HRmax in the tests from 2014.

Moreover, concurrent decreases in HRmax and lactate concentration with increases in the levels of endurance skills were found among female handball and basketball players and male soccer players. Although these changes were statistically non-significant, they indicate proper adaptive tendencies in developing players' endurance skills. An increasing tendency in the covered distance was also observed in female soccer and volleyball players and in male basketball players; however, their physiological-biochemical reactions were ambiguous and did not indicate and anticipate adaptation to endurance efforts. The question remains whether these changes were the result of rational training or natural development. A number of authors have observed that that human motor fitness during the period of progressive development is mainly associated with somatic development $[1,6]$. Team sports coaches often select children who develop faster and are a few months older than their peers [35]. However, during a subsequent period of training, individuals who are biologically older do not show significant improvements inmotor skills in comparison with those who develop more gradually [26].

\section{CONCLUSIONS}

Significantly higher levels of endurance skills in young male handball, basketball and volleyball players and in female volleyball players who remained on the regional teams for two years may be evidence of their proper selection and optimal training.

Significant changes in blood lactate concentration in young team games players revealed in cross-sectional and continuous studies were only found in young male volleyball players. The players who remained on their teams for two years had a higher blood lactate level following the Beep Test. This can be indicative of their higher tolerance to incremental fatigue. The lower lactate concentration in the continuous studies in 2014 and, simultaneously, a significantly longer distance covered in the incremental test indicate proper adaptation of the players' bodies to performing endurance exercise tests.

A significantly lower heart rate in the cross-sectional studies was observed only in male handball and basketball players and female basketball players, whereas in the continuous studies lower HR was only found in male handball players. These results can also reveal the body's proper adaptation to developing endurance skills. The estimation of physiological-biochemical reactions through exercise tests can effectively enhance the optimization of training loads. Further research is necessary to provide more data on young talented athletes, especially during the period of their most intensive biological development.

\section{ACKNOWLEDGEMENTS}

The study was financially supported by the Polish Ministry of Research and Higher Education program "Development of Academic Sport in Poland, 2013" (research project no. RSA2 019 52: "Estimation of young people's predispositions to train sport team games"). 


\section{REFERENCES}

[1] Misiolek E, Korzewa L. Sprawnosc motoryczna chlopcow uprawiajacych pilke reczna w momencie naboru I po dwoch latach szkolenia na tle populacji wroclawskiej [Motor efficiency of boys practising handball at the time of recruitment and after two years of training compared to the population of Wroclaw]. Rozprawy Naukowe Akademii Wychowania Fizycznego we Wroclawiu. 2012;39:177-184. Polish.

[2] Reilly T, Williams AM, Nevill A, Franks A. A multidisciplinary approach to talent identification in soccer. J Sports Sci. 2000;18(9):695-702.

[3] Trnicic S, Papic V, Trnicic V, Vukiceuic D. Player selection procedures in team sports game. Acta Kinesiologica. 2008;2(1):24-28.

[4] Ie Gall F, Carling C, Williams M, Reilly T. Anthropometric and fitness characteristics of international, professional and amateur male graduate soccer players from an elite youth academy. J Sci Med Sport. 2010;13:90-95.

[5] Ré AHN, Cattuzzo MT, Santos FMC, Monteiro CBM. Anthropometric characteristics, field test scores and match-related technical performance in youth indoor soccer players with different playing status. Int J of Perform Anal Sport. 2014;14:482-492.

[6] Malina RM, Cumming SP, Kontos AP, Eisenmann JC, Ribeiro B, Aroso J. Maturity-associated variation in sport-specific skills of youth soccer players aged 13-15 years. J Sports Sci. 2005;23(5):515-22.

[7] Halson SL. Monitoring training load to understand fatigue in athletes. Sports Med. 2014;44 Suppl 2:139-47.

[8] Chmura J. Rozgrzewka. Podstawy fizjologiczne i zastosowanie praktyczne [Warm-up. Physiological basics and practical application]. Wydanie I, Warszawa: Wydawnictwa Lekarskie PZWL; 2014. Polish.

[9] Jastrzebski Z, Glowacki A, Rompa P, Stepien P, Radziminski L. Obciazenia treningowe a poziom wybranych zdolnosci motorycznych mlodych pikarzy noznych w rocznym cyklu szkolenia [Training loads and the level of the selected motor skills in young soccer players in an annual training cycle]. In: Jastrzebski Z, editor. Teoria i praktyka wychowania fizycznego i sportu. T. 1 [Theory and practice of physical education and sports. Vol. 1]. Lodz: Wyzsza Szkola Sportowa; 2012. Polish.

[10] Akubat I, Patel E, Barrett S, Abt G. Methods of monitoring the training and match load and their relationship to changes in fitness in professional youth soccer players. J Sports Sci. 2012;30(14):1473-80.

[11] Carling C. Analysis of physical activity profiles when running with the ball in a professional soccer team J Sports Sci. 2010;28(3):319-326.

[12] Jaskulska E, Bichowska M, Bargowski M, Stepien P, Jastrzebski Z. Ocena obciazen treningowych I wydolnosci fizycznej pilkarzy noznych juniorow w okresie przygotowawczym [Evaluation of training loads and physical capacity of soccer players during the preparatory period]. In: Jastrzebski Z, editor. Teoria i praktyka wychowania fizycznego i sportu. T. 2 [Theory and practice of physical education and sports. Vol. 2.] Lodz: Wyzsza Szkola Sportowa; 2012. Polish.

[13] Payne SM, Hudson J, Akehurst S, Ntoumanis N. Development and initial validation of the Impression Motivation in Sport Questionnaire - Team. J Sport Exerc Psychol. 2013;35(3):281-98.

[14] Causer J, Ford PR. "Decisions, decisions, decisions": transfer and specificity of decision-making skill between sports. Cogn Process. 2014;15(3):385-9.

[15] Ostojic SM, Mazic S, Dikic N. Profiling in basketball: physical and physiological characteristics of elite players. J Strength Cond Res. 2006;20(4):740-4.

[16] Buchheit M, Laursen PB. High-intensity interval training, solutions to the programming puzzle. Part II: anaerobic energy, neuromuscular load and practical applications. Sports Med. 2013;43(10):927-54.

[17] Chmura J. Chmura P. Ciaston J. Przygotowanie motoryczne do wysilku startowego [Motor preparation for competitive effort]. Sport Wyczynowy. 2008;10-12;49-61. Polish.

[18] Carvalho HM, Bidaurrazaga-Letona I, Lekue JA, Amado M, Figueiredo AJ, Gil SM. Physical growth and changes in intermittent endurance run performance in young male Basque soccer players. Res Sports Med. 2014;22(4):408-24.

[19] Gronek P, Holdys J. Genes and physical fitness. Trends Sport Sci. 2013;1(20):16-29.

[20] Gronek P, Holdys J, Konarski J, Krysciak J, Wolc A. ACE I/D genotype in professional field hockey players. Trends Sport Sci. 2013;1(20):36-40.

[21] Coutts AJ, Reaburn P, Piva TJ, Rowsell GJ. Monitoring for overreaching in rugby league players. Eur J Appl Physiol. 2007;99(3):313-24.

[22] Nikolaidis PT. Age-predicted vs. measured maximal heart rate in young team sport athletes. Niger Med J. 2014;55(4):314-20.

[23] Randers MB, Andersen TB, Rasmussen LS, Larsen MN, Krustrup P. Effect of game format on heart rate, activity profile, and player involvement in elite and recreational youth players. Scand J Med Sci Sports. 2014:24 (1):17-26.

[24] Bangsbo J, Mohr M, Krustrup P. Physical and metabolic demands of training and match-play in the elite football player. J Sport Sci. 2006;24(7):665-74.

[25] Le Meur Y, Hausswirth C, Natta F, Couturier A, Bignet F, Vidal PP. A multidisciplinary approach to overreaching detection in endurance trained athletes. J Appl Physiol. 2013;114(3):411-20.

[26] Léger LA, Lambert J. A maximal multistage 20-m shuttle run test to predict VO2max. Eur J Appl Physiol 1982;49(1):1-12.

[27] Léger LA, Mercier D, Gadoury C, Lambert J. The multistage 20-metre shuttle run test for aerobic fitness. J Sports Sci. 1988 6:93-101.

[28] Kobiałka K, Kawczynski A, Mroczek D, Klimek A, Chmura J. Blood lactate concentrations in the top Polish sprinters during the 100-meter dash. JKES. 2014;24(24):23-27. 
[29] Kobialka K, Chmura P, Kawczynski A, Mroczek D, Lisowski J, Chmura J. Activity of the anaerobic glycolysis of top Polish sprinters specialising in $400 \mathrm{~m}$ run during the $300 \mathrm{~m}$ competition. Sport Wyczynowy. 2013;2:58-63.

[30] Paradisis GP, Zacharogiannis E, Mandila D, Smirtiotou A, Argeitaki P, Cooke CB. Multi-stage 20-m shuttle run fitness test, maximal oxygen uptake and velocity at maximal oxygen uptake. J Hum Kinet. 2014;41:81-87.

[31] Stølen T, Chamari K, Castagna C, Wisløff U. Physiology of soccer: an update. Sports Med. 2005;35(6):501-36.

[32] Beniscelli V, Tenenbaum G, Schinke RJ, Torregrosa M. Perceived distributed effort in team ball sports. J Sports Sci. 2014;32(8):710-21.

[33] Zuber C, Zibung M, Conzelmann A. Motivational patterns as an instrument for predicting success in promising young football players. J Sports Sci. 2014;18:1-9.

[34] Mroczek D, Januszkiewicz A, Kawczynski A, Borysiuk Z, Chmura J. Analysis of male volleyball players' motor activities during a top level match. J Strength Cond Res. 2014;28(8):2297-2305.

[35] Gastin PB, Bennett G. Late maturers at a performance disadvantage to their more mature peers in junior Australian soccer. J Sport Sci. 2014;32(6):563-571. 